\title{
Title-An Extrapolation to Small Round Blue Cell Tumor Diagnosed as Esthesioneuroblastoma -Acase Series
}

\author{
Dr. Arnav Sahu, ${ }_{1}^{1}$ Dr.Anu Singh ${ }^{2}$, Dr Abhishek Verma ${ }^{3}$, Dr Trilochan Singh ${ }^{4}$, \\ Dr. R.K. Srivastava ${ }^{5}$, Dr Ratna Chaudhari ${ }^{6}$, Dr Ravi Murmu ${ }^{7}$ \\ ${ }^{1} J R 3$, MS Orthopaedics, St John's Medical College, Bangalore, \\ ${ }^{2} J R 3$, MD Pathology, \\ ${ }^{3}$ Senior Resident, Department of transfusion medicine, \\ ${ }^{4} \mathrm{HOD}$, Department of Pathology, \\ ${ }^{5}$ Professor, Department of pathology, \\ ${ }^{6}$ professor, department of pathology, \\ ${ }^{7} \mathrm{JR} 3$, Department of pathology, Rajendra Institute of Medical Sciences, Ranchi,
}

\begin{abstract}
Small round blue cell tumor is a very common diagnostic finding after intraoperative diagnostic procedures such as squash cytology or frozen section. After proper biopsy techniques, histopathological diagnosis and immunohistochemistry confirmation, diagnosis of Esthesioneuroblastoma is established. Due to its aggressiveness and high recurrence rate, it is mandatory to diagnose this tumor as soon as possible. In our three year study period, only 3 cases of Esthesioneuroblastoma were reported in which extensive Immunohistochemistry panel played an important role to differentiate it from others and come to a conclusive diagnosis. These cases were first diagnosed through squash cytology as a small round blue cell and later confirmed as Esthesioneuroblastoma by histopathology and immunohistochemistry with synaptophysin, chromogranin, CD 56, CD 99. MIB-1 played an important role to grade the tumor according to Hyam's histological grading.
\end{abstract}

Keywords: olfactory, neuroblastoma, squash cytology, biopsy, immunohistochemistry,

\section{Introduction}

Esthesioneuroblastoma is an extremelyrare neoplasm with an incidence of 0.4 per 1,000,000 people. ${ }^{1}$ it is a locally aggressive idiopathic neoplasm of sinonasal area arising from olfactory neuroepithelium and its clinical course is characterised by indolent growth, persistent local recurrence and occasional distant metastasis. It has a wide range of age presentation $(3-79 y r s)$, mostly showing bimodal age distribution which peaks around first and fifth decade ${ }^{2,3}$. Its probable site of origin is neuroectodermal. Being more precise, it is believed to originate from sustentacular cells of olfactory neuroepithelium in upper third of nasal septum, cribriform plate and superior turbinate. It has been given various terminologies such as olfactory placode tumor, esthesioneurocytoma, esthesioneuroepithelioma, and esthesioneuroma. It is classified into 4 grades on the basis of Hyam's histological grading. Extent and survival rate is classified by Kaddish clinical staging system as discussed later.

Case history

As found in various studies, Esthesioneuroblastoma typically presents with unilateral nasal obstruction or epistaxis. ${ }^{4-6}$ but in the 3 cases studied in our department, following clinical features were predominantly noticed.

1. 20 yrs. male presented with c/o left sided nasal obstruction, epistaxis, headache, anosmia and dimness of vision abnormal facies.

2. 35 yrs male presented with c/o large tumor in frontal region (extradural lesion involving orbit and maxilla eroding bone) restricting field of vision, proptosis.

3. 4 yrs female child presented with nasal mass with difficulty in breathing
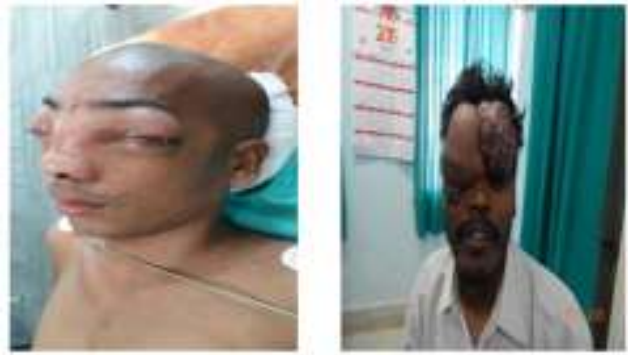

DOI: 10.9790/0853-1508034347 www.iosrjournals.org

43 | Page 
Title-An Extrapolation To Small Round Blue Cell Tumor Diagnosed As Esthesioneuroblastoma..

These cases were first diagnosed by intraoperative squash cytology and later confirmed by histopathology and immunohistochemistry with synaptophysin, chromogranin, CD 56, CD99, MIB1.

Table 1 Clinical Findings in Three Cases of Esthesioneuroblastoma

\begin{tabular}{|c|c|c|c|c|c|c|c|}
\hline Case & Sex & $\begin{array}{l}\text { Age(y } \\
\text { ears) }\end{array}$ & Location and size & Symptoms & Treatment & Complications & $\begin{array}{l}\text { Follow-up } \\
\text { (from } \\
\text { diagnosis) }\end{array}$ \\
\hline 1 & $\mathrm{M}$ & 20 & $\begin{array}{l}\text { Arising from nasal } \\
\text { cavity } \\
7 * 7 * 5 \mathrm{~cm}\end{array}$ & $\begin{array}{l}\text { Headache, } \\
\text { anosmia, }\end{array}$ & $\begin{array}{l}\text { Complete surgical } \\
\text { excision of tumor } \\
\text { craniofacial approach }\end{array}$ & $\begin{array}{l}\text { On table death } \\
\text { due to } \\
\text { extensive } \\
\text { metastasis. }\end{array}$ & $\begin{array}{l}\text { Patient died due } \\
\text { to operative } \\
\text { complications }\end{array}$ \\
\hline 2 & $\mathrm{M}$ & 35 & $\begin{array}{l}\text { Arising from medial } \\
\text { orbital wall eroding } \\
\text { maxilla and frontal } \\
\text { bone extending to } \\
\text { nasal cavity } \\
8.8 * 8.4 * 11 \mathrm{cms}\end{array}$ & $\begin{array}{l}\text { Visual } \\
\text { disturbances, } \\
\text { lachrymation }\end{array}$ & 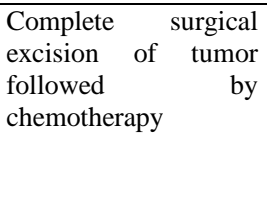 & $\begin{array}{l}\text { Residual tumor } \\
\text { left }\end{array}$ & $\begin{array}{l}\text { Patient reported } \\
\text { with recurrence. }\end{array}$ \\
\hline 3 & $\mathrm{~F}$ & 4 & Nasal mass & $\begin{array}{l}\text { Nasal } \\
\text { obstruction, } \\
\text { difficulty in } \\
\text { breathing }\end{array}$ & $\begin{array}{l}\text { Complete endoscopic } \\
\text { surgical excision of } \\
\text { tumor followed by } \\
\text { chemotherapy and } \\
\text { radiotherapy }\end{array}$ & $\begin{array}{l}\text { Operative } \\
\text { procedure was } \\
\text { uneventful }\end{array}$ & $\begin{array}{l}\text { Patient has not } \\
\text { reported yet } \\
\text { with recurrence } \\
\text { or any } \\
\text { complaints. }\end{array}$ \\
\hline
\end{tabular}

Radiological Findings

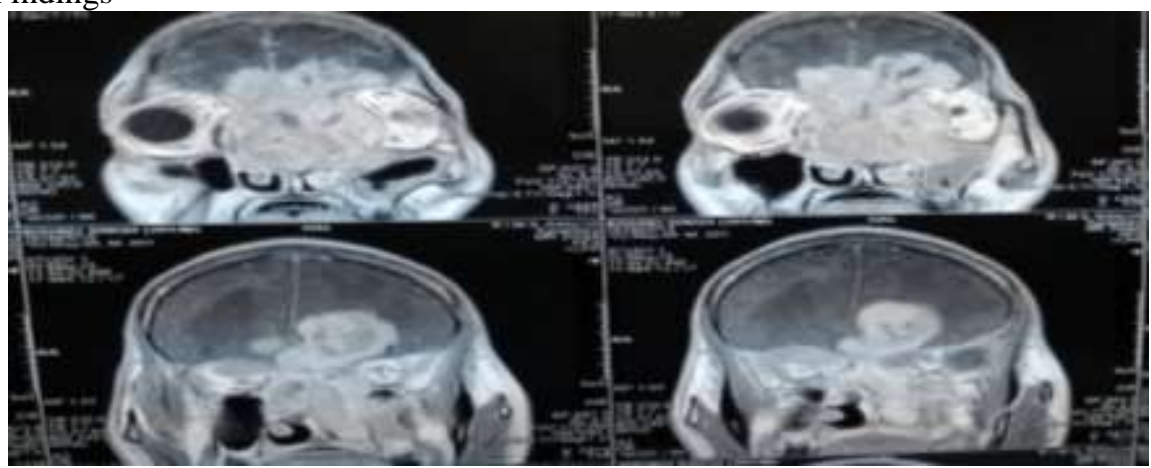

Figure1 Showing Large Lesion Of Size 7 X 7 X 5 Cm Heterogeneous Mass Arising From Nasal Cavity With Extension Into Ant. Cranial Fossa And B/L Orbit, Frontal, Ethmoidal Sinus, Maxillary Sinus Causing Adjacent Bony Destruction
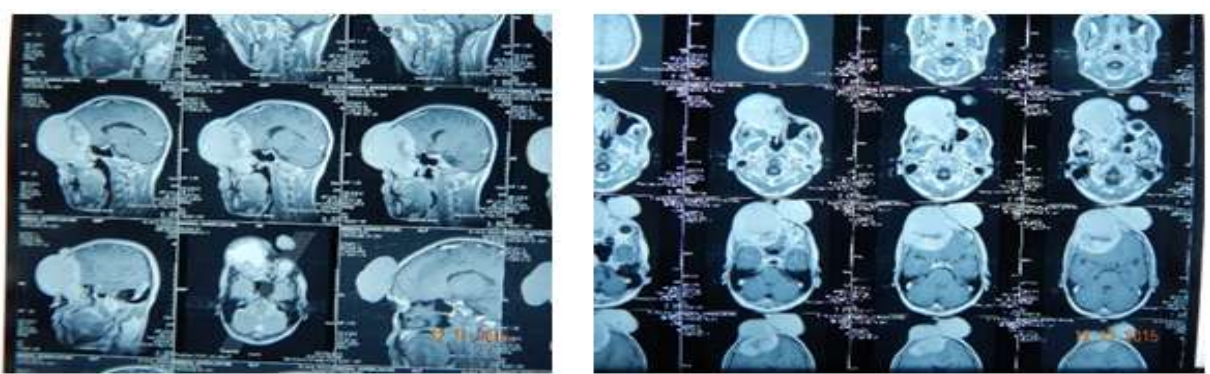

Figure 2showing a large heterodense soft tissue lesion arising from medial wall of orbit involving orbital floor, maxillary \& ethmoid nasal sinuses and nasal cavity.no midline shift .brain and optic nerve intact

Craniofacial resection en bloc is the surgery of choice for Esthesioneuroblastoma. In Third case endoscopic craniofacial resection was done for the child.In second case bone resection and graft placement was also followed the basic operative procedure.In the first case, dacryocystorhinostomyand frontal sinusotomy was also planned which couldn't be executed due to on-table death. During operative procedures, first case was described as Kadish stage D due to the tumor metastasis to distant cervical lymph nodes, Second case was established as Kadish stage $\mathrm{C}$ due to extension beyond paranasal sinuses. The tumor was so aggressive that it eroded the frontal, maxillary bone and orbital wall. Third case which affected a young child was observed as Kadish stage B due to its limitation to paranasal sinuses.

Macroscopic Features - In first case it was a lobulated mass measuring 10x3x3 cm greyish white in colour, firm in consistency. Cut open section showed few necrosed and calcification areas. In the second case, 
Title-An Extrapolation To Small Round Blue Cell Tumor Diagnosed As Esthesioneuroblastoma..

a20*6*5 cmsirregular polypoid mass was dissected. Cut open Section showed large areas of haemorrhage and necrosis. In the third case a $4 * 3 * 2 \mathrm{cms}$ globular mass was endoscopically resected which showed no evidence of haemorrhage or necrosis.
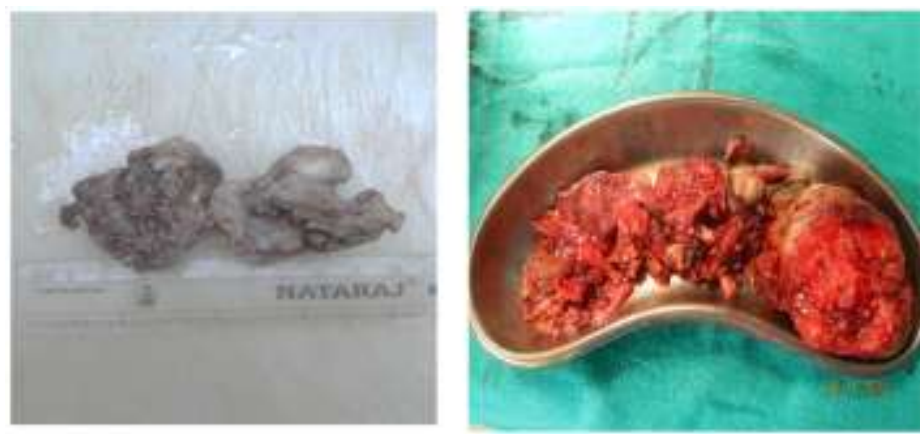

Microscopic Features - On squash cytology there were Rosette like structure composed of small round cells around a fibrillary centre and cells with fragile cytoplasm and small round nuclei with speckled chromatin.
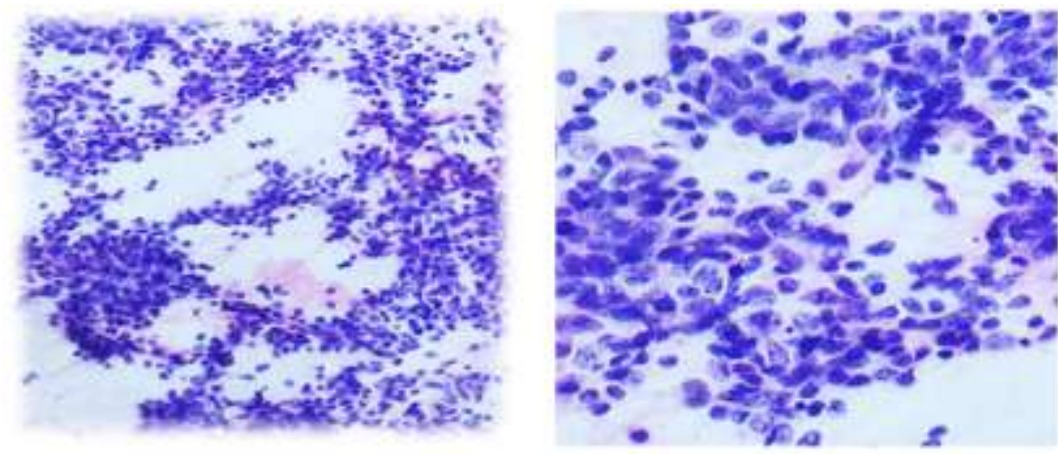

Histopathological examination showed lobular architecture with uniform appearing round cells surrounded by a neurofibrillary material
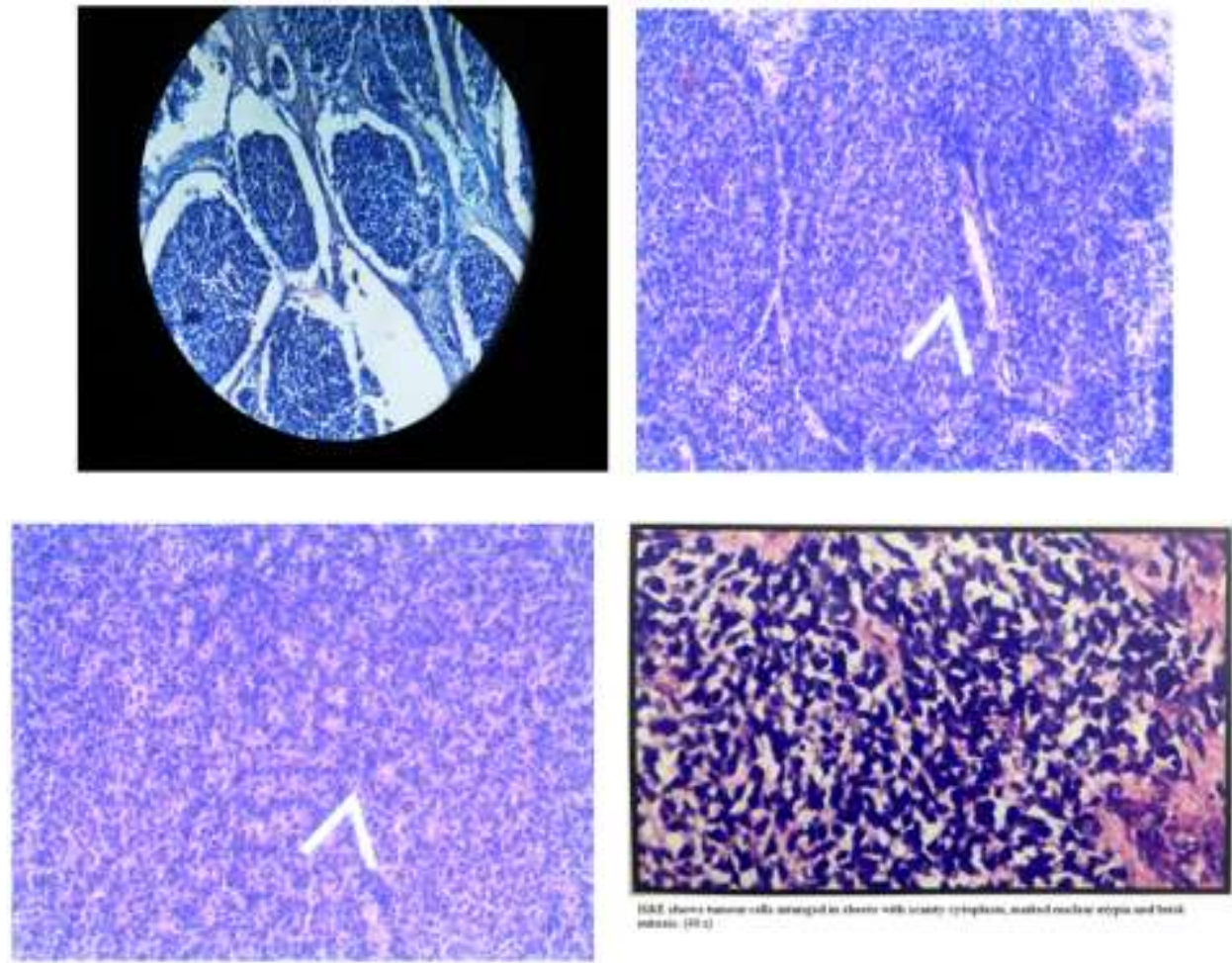

istimition 
High power view shows Homer Wright pseudo rosettes characterized by grouping of cells in a circumferential fashion around neurofibrillary matrix but without a defining basement membrane.

High-grade neoplasm lacks neurofibrillary matrix and includes a pleomorphic cellular infiltrate with increased mitotic activity

Immunohistochemistry
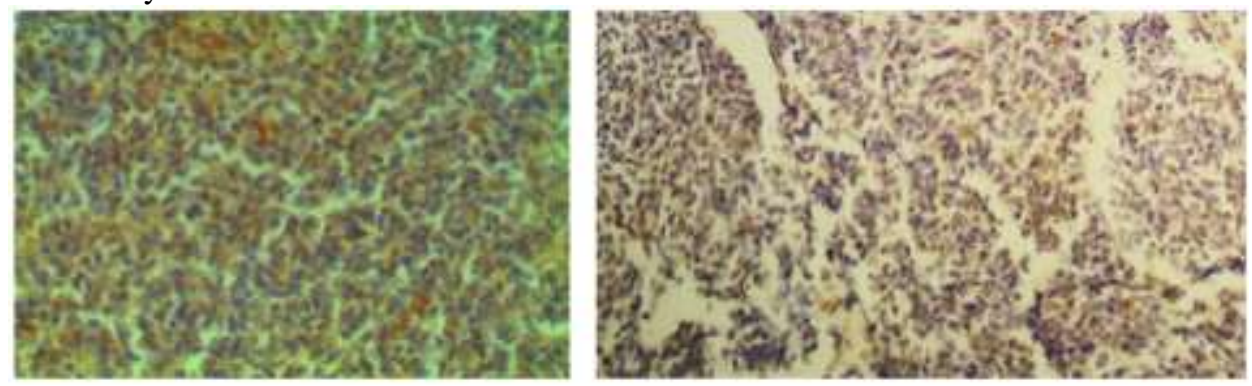

Synaptophysin chromogranin
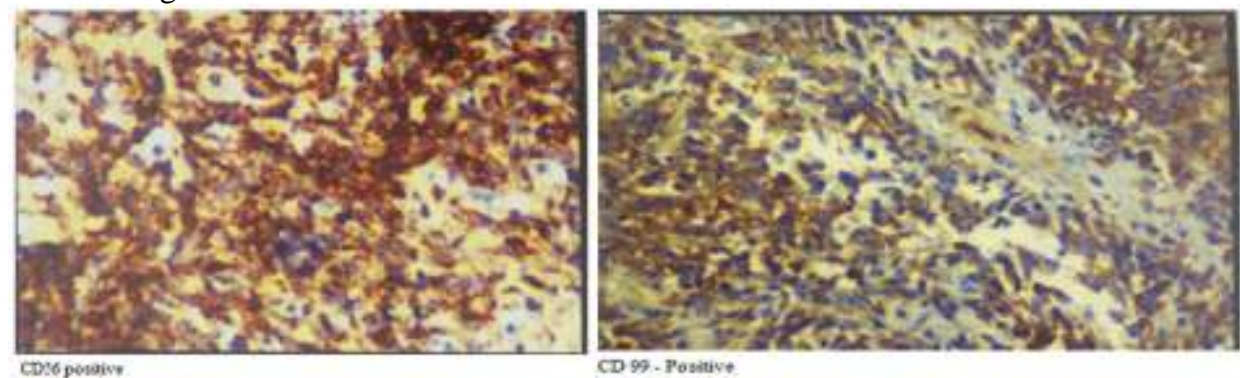

CDso penais CD 99 - Positive

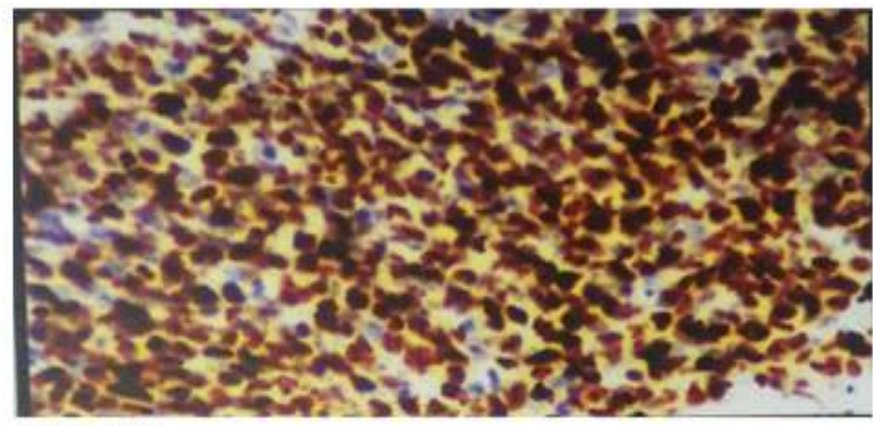

Mab-1 $=90 \%$

MIB - 1 is done to evaluate the proliferative index so that Hyam's histological grading can be done properly.

II. Results

\begin{tabular}{|l|l|l|l|l|}
\hline CASE & $\begin{array}{l}\text { KADISH } \\
\text { CLINICAL } \\
\text { STAGING }\end{array}$ & $\begin{array}{l}\text { DIAGNOSIS ONTRAOPEATIVE SQUASH } \\
\text { INTRAOPER } \\
\text { CYTOLOGY }\end{array}$ & $\begin{array}{l}\text { DIAGNOSIS ON BIOPSY } \\
\text { HYAM'S } \\
\text { HISTOLOGICAL } \\
\text { GRADING }\end{array}$ \\
\hline CASE 1 & Stage D & Small Round Blue Cell tumor & Esthesioneuroblastoma & Grade 4 \\
\hline CASE 2 & Stage C & Small Round Blue Cell tumor & Esthesioneuroblastoma & Grade 2 \\
\hline CASE 3 & Stage B & Small Round Blue Cell tumor & Esthesioneuroblastoma & Grade 3 \\
\hline
\end{tabular}

\section{Discussion}

Esthesioneuroblastoma is mostly classified under two broader diagnostic terms sinonasal neuroendocrine malignancies or small round blue cell tumors. The differential diagnosis which should be considered are Malignant lymphoma(NHL), primary melanoma, Plasmacytoma, Embryonal/ alveolar rhabdomyosarcoma, Ewing sarcoma/ primitive neuroectodermal tumour, Sinonasal Undifferentiated carcinoma, Sinonasal neuroendocrine carcinoma and Small cell carcinoma. Though the patient presents with the symptoms quite late, early diagnosis is very important due to complex anatomical site and aggressiveness of the tumor. The pathologic grading system for Esthesioneuroblastomadeveloped by Hyam's is as follows:- 


\begin{tabular}{|c|c|c|c|c|}
\hline \multicolumn{5}{|c|}{ Hyams' Histologic Grading System for Olfactory Neuroblastoma ${ }^{341}$} \\
\hline Microscopic Features & Grade 1 & Grade 2 & Grade 3 & Grade 4 \\
\hline Architecture & Lobular & Lobular & \pm Lobular & \pm Lobular \\
\hline Pleomorphism & Absent to slight & Present & Prominent & Marked \\
\hline NF matrix & Prominent & Present & May be present & Absent \\
\hline Rosettes & Present ${ }^{*}$ & Present ${ }^{*}$ & May be present ${ }^{t}$ & May be present ${ }^{t}$ \\
\hline Mitoses & Absent & Present & Prominent & Marked \\
\hline Necrosis & Absent & Absent & Present & Prominent \\
\hline Glands & May be present & May be present & May be present & May be present \\
\hline Calcification & Variable & Variable & Absent & Absent \\
\hline
\end{tabular}

Reproduced fromHyam's V J 1982 Olfactory neuroblastoma (case 6). In: Batsakis J G, Hyam's V J, Morales A $\mathrm{R}$ (ends) Special tumors of the head and neck. ASCP Press, Chicago, p 24-29

$N F$, Neurofibrillary.

*Homer Wright rosettes (pseudo rosettes).

$\dagger$ Flexner-Wintersteiner rosettes (true neural rosettes).

Grade I tumors have excellent prognosis and grade IV have worst prognosis with uniformly fatal outcome. For staging purposes, the best known and widely used system is that devised by Kadish ${ }^{[7]}$ and modified by Morita. [8]

\section{Kadish Staging with Morita's Modification}

A - Limited to nasal cavity $75-90 \%$

B - Involving nasal cavity \& sinuses $67-71 \%$

C - Extension beyond nasal \& paranasal sinuses cavities $41-47 \%$

D - Tumor with metastasis to cervical nodes or distant sites $<40 \%$

Thus, it is important to clinically stage the tumor and histologically grade followed by prompt resection.It is important to follow-up the patient post-operatively due its high recurrence rate. The reported locoregional recurrence rate in Esthesioneuroblastoma ranges from 27 to $62 \%$ with most recurrences within first two years of diagnosis ${ }^{[9,10]}$. Few paraneoplastic syndromes have also been reported, most common being Syndrome of inappropriate Antidiuretic hormone secretion. ${ }^{11}$ Henceforth, it is important to diagnose the patient of Esthesioneuroblastoma as soon as possible and resect the tumor along with tumor margins followed by radiotherapy and chemotherapy.

\section{Acknowledgement}

I would like to thank all the staff and technicians of pathology department, Rajendra Institute of medical sciences.

\section{References}

[1]. Theilgaard SA, Buchwald C, Ingeholm P, Kornum Larsen S, EriksenJG, Sand HansenH. Esthesioneuroblastoma: a Danish demographicstudy of 40 patients registered between 1978 and 2000. Acta Otolaryngol 2003;123:433-439

[2]. Wormald R, Lennon P, O'Dwyer TP: Ectopic olfactory neuroblastoma:report of four cases and a review of the literature. Eur ArchOtorhinolaryngol 2011, 268:555-560.

[3]. Benoit MM, Bhattacharyya N, Faquin W, Cunningham M: Cancer of thenasal cavity in the pediatric population. Pediatrics 2008, 121:141-145.

[4]. Dulguerov P, Allal AS, Calcaterra TC. Esthesioneuroblastoma: ameta-analysis and review. Lancet Oncol 2001;2:683-690

[5]. Elkon D, Hightower SI, Lim ML, Cantrell RW, Constable WC.Esthesioneuroblastoma. Cancer 1979;44:1087-1094

[6]. Kane AJ, SughrueME, Rutkowski MJ, et al. Posttreatment prognosisof patients with esthesioneuroblastoma. J Neurosurg 2010;113:340-351

[7]. Kadish S, Goodman M, Wang CC. Olfactory neuroblastoma: a clinicalanalysis of 17 cases. Cancer 1976;137:1571-6.

[8]. Morita A, Ebersold MJ, Olsen KD, Foote RL, Lewis JE, Quast LM.Esthesioneuroblastoma: prognosis and management. Neurosurgery 1993;32:706-15

[9]. Constantinidis J, Steinhart H, Koch M, Buchfelder M, Schaenzer A,Weidenbacher M, et al. Olfactory neuroblastoma: The University ofErlangen-Nuremberg experience 1975-2000. Otolarygol Head Neck Surg 2004;130:567-74.

[10]. Loy AH, Reibel JF, Read PW, Thomas CY, Newman SA, Jane JA, et al.Esthesioneuroblastoma: continued follow up of a single institution'sexperience. Arch Otolaryngol Head Neck Surg 2006;132:134-8.

[11]. Ear Nose Throat J. 2013 Oct-Nov;92(10-11):E6. A case and a series of published cases of esthesioneuroblastoma (ENB) in which long-standing paraneoplastic SIADH had preceded ENB diagnosis.Gabbay U ${ }^{1}$, Leider-Trejo L, Marshak G, Gabbay M, Fliss DM. 